\title{
Archaeological and Historical Assessment of Brackenridge Park City of San Antonio, Texas
}

Susanna R. Katz

Anne A. Fox

Follow this and additional works at: https://scholarworks.sfasu.edu/ita

Part of the American Material Culture Commons, Archaeological Anthropology Commons, Environmental Studies Commons, Other American Studies Commons, Other Arts and Humanities Commons, Other History of Art, Architecture, and Archaeology Commons, and the United States History Commons

Tell us how this article helped you.

This Article is brought to you for free and open access by the Center for Regional Heritage Research at SFA ScholarWorks. It has been accepted for inclusion in Index of Texas Archaeology: Open Access Gray Literature from the Lone Star State by an authorized editor of SFA ScholarWorks. For more information, please contact cdsscholarworks@sfasu.edu. 


\section{Archaeological and Historical Assessment of Brackenridge Park City of San Antonio, Texas}

\section{Creative Commons License}

\section{(c) (1) (8)}

This work is licensed under a Creative Commons Attribution-NonCommercial 4.0 International License 


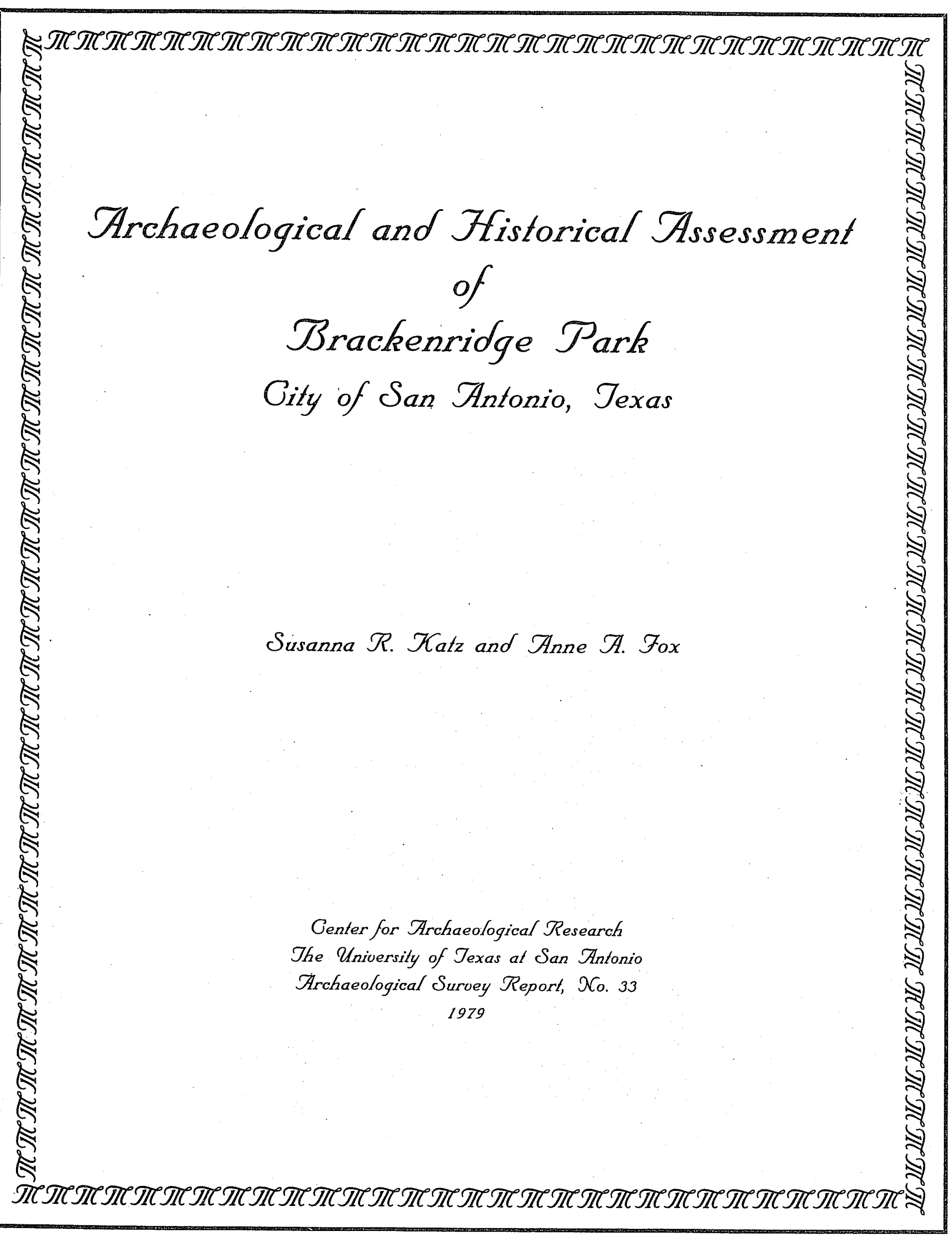




\section{ARCHAEOLOGICAL AND HISTORICAL ASSESSMENT OF \\ BRACKENRIDGE PARK, CITY OF SAN ANTONIO, TEXAS}

Susanna R. Katz and Anne A. Fox

Center for Archaeological Research The University of Texas at San Antonio Archaeological Survey Report, No. 33 1979 
List of Figures .................. . . Acknowledgments ................... . .

General Introduction . . . . . . . . . . . . 1

The Prehistoric Sites. . . . . . . . . . . . . . 2

Introduction .................... 2

Archaeological Background ............... . . 2

Survey Procedures . . . . . . . . . . . . . . 3

Results of the Survey. . . . . . . . . . . . . 5

Summary and Recommendations ... . . . . . . . . . . 11

The Historic Sites. . . . . . . . . . . . . . . . . . 12

Water Control Features . . . . . . . . . . . . 12

Industrial structures. . . . . . . . . . . . . 14

Recreational Features. . . . . . . . . . . 18

Educational Facilities............... . . 19

Miscellaneous Features.............. . 21

Recommendations................ 21 21

Summary and Conclusions . . . . . . . . . . . . . . 22

References Cited. . . . . . . . . . . . . 23 


\section{LIST OF FIGURES}

Figure

Page

1. Map of Brackenridge Park and Brackenridge Golf Course . . . . . 4

2. Views of Prehistoric Sites. . . . . . . . . . . . . . 6

3. Views of Prehistoric Sites. . . . . . . . . . . . . . . 8

4. Historic Sites Map of Brackenridge Park and Brackenridge

Golf Course .. . . . . . . . . . . . . . . . . 13

5. Views of Historic Sites . . . . . . . . . . . . . . . 15

6. Views of Historic Sites . . . . . . . . . . . . . . . . 17 


\section{ACKNOWLEDGMENTS}

We gratefully acknowledge the aid and cooperation provided by Ron Darner, Director, and Ed Davis and John Laffoon of the staff of the San Antonio Parks and Recreation Department, and by architect Pete 01 fers of CGR Associates. As always, we are indebted to the librarians at the DRT Library, the San Antonio Public Library, the Ellen S. Quillin Library of the Witte Museum and the San Antonio Conservation Society Library for making their facilities available and for helping in numerous ways.

Paul Katz, Research Associate with the Center for Archaeological Research, The University of Texas at San Antonio, gave unlimited assistance in all phases of this project. His expertise was greatly appreciated.

The following persons volunteered their time and talents to survey of the park: Carolyn Furman, Theresa Hammonds, Rebecca Martin and Cynthia Tron, students from Incarnate Word College.

Historical research for the project was carried out by Sara E. Kleine of the Center staff. James E. Ivey, Research Associate, Center for Archaeological Research, participated in the survey and laboratory work. Lynn Hightey of the Center also assisted with the laboratory analysis.

The project was carried out under the overall supervision of Dr. Thomas R. Hester, Director of the Center for Archaeological Research, and Jack D. Eaton, Associate Director. The manuscript was typed by Frieda Barefield of the Center staff. 
GENERAL INTRODUCTION

During the last weeks of December 1976, an archaeological and historical survey was conducted within the boundaries of Brackenridge Park, San Antonio, Texas, to inventory and assess all identifiable prehistoric and historic remains. This survey resulted from a contract between the Center for Archaeological Research (CAR), The University of Texas at San Antonio (UTSA), and the San Antonio Parks and Recreation Department, in conjunction with the preparation of a master plan for future park development. The master plan is currently being prepared by the firm of CGR Associates of San Antonio. Dr. Thomas R. Hester, Director of CAR, served as principal investigator for the project, and the work was coordinated by Jack Eaton, Associate Director.

The report describes the various activities of these surveys and details the results of both field surveys and laboratory and library/archival research. Each prehistoric and historic site is described, including location, physical description of structure(s), date and function.

Brackenridge Park is a City-owned facility, located approximately one mile north of downtown San Antonio. The park is bounded by Broadway and Hildebrand Avenues and the McAllister Expressway.

A portion of present-day Brackenridge Park was part of the original grant from the King of Spain to the Municipality. All property that was held by individuals or business concerns has either been donated to the City for park purposes or acquired by the City through condemnation or purchase. Consequently, although the area under consideration is generally thought of as "Brackenridge Park, "it was actual1y acquired through a number of separate activities and at different times.

The nucleus of Brackenridge Park was developed on land donated through deed of gift to the City from the Water Works Company through George W. Brackenridge. This gift, accepted by the City Council on November 20, 1899, included 199.44 acres of land east of the San Antonio River and a 45-acre tract to the west. It was bounded by the river, the Otto Koehler property, Avenue B and Josephine Street. It did not include, however, direct access from the park onto Broadway; and it was thus necessary to cross over property still owned by the Water Works Company to gain entry. Shortly after Brackenridge sold his interest in the Water Works Company in 1905, the San Antonio Water Supply Company (as it was then known) closed off the access to the park. This rather awkward situation was rectified by condemnation and purchase procedures in which the city acquired a frontage area.

The necessity of the condemnation suit and the purchase brought to a head some resentment toward Brackenridge that had been building for some years, and Brackenridge was held responsible by some City officials for this situation. This culminated on May 22, 1911 in City Council voting to change the name of the park from Brackenridge Park to Water Works Park. The original name was reinstated on July 7, 1913. 
Koehler Park was donated by Emma Koehler in 1915 in memory of her late husband, 0tto. The City accepted the 10.93-acre gift and added an additional 3.37 acres of its own to the park. A restriction against the sale of malt liquors, which was stipulated in the Water Works deed, did not apply to the Koehler donation; in fact, the sale of malt liquor as well as non-alcoholic beverages was encouraged. Consequently, this is the major food and drink concession area in the park.

In 1917 Brackenridge added three tracts to the park, connecting the area between Koehler Park with the San Antonio River and the Upper Labor ditch. A7so in 1917, the County Commissioners Court gave a tract of land for park purposes southwest of the Brackenridge Park, east of North St. Mary's at Mulberry. The City also purchased the area called Lion's Field from the Water Supply Company between 1916 and 1920. The park has remained intact except for the sale of 2.12 acres to the Sunshine Cottage School for Deaf Children in 1951. (Historical information for this section has been compiled from Balmos 1959, King 1950 and Newcomb 1962.)

\section{THE PREHISTORIC SITES}

\section{Introduction}

This section summarizes the results of an archaeological survey conducted in December 1976 in Brackenridge Park and on Brackenridge Golf Course, San Antonio, Texas. The survey documented the presence of prehistoric occupation and utilization in this area for possibly as long as 8000 years.

\section{Archaeological Background}

Professional archaeological investigation is a fairly recent activity in the Brackenridge Park area. In the vicinity of the park, there is little of note prior to Anne Fox's 1975 survey of the Incarnate Word College property immediately north of the park. This survey resulted in the description of 13 prehistoric and historic sites (Fox 1975), several of which are now designated as State Archaeological Landmarks. The entire survey area has been nominated as a District on the National Register of Historic Places. Excavation of Incarnate Word College sites began in summer 1976 as a longrange field school project of the College's Native American Studies Program, under the direction of Susanna and Paul Katz.

In addition to work by Fox and the Katzes in this area, there have been several other sites recorded. C. D. Orchard has made extensive collections in the $01 \mathrm{mos}$ Basin over several decades, both from the Incarnate Word property and from 41 BX 1 north of 01mos Dam (Orchard 1966, 1974). Some of Orchard's collection is currently stored at the Witte Museum, although most of it (along with his field notes) is at his home at Lake McQueeney, Texas. 
Prior to the construction of the Northeast Expressway, which bounds the golf course, Brackenridge Park and Incarnate Word College on the west, the Texas Highway Department conducted a limited testing program along the rightof-way. No new archaeological sites were recorded south of 01 mos Dam, although test pits immediately west of Incarnate Word College did yield chipped stone flakes and several tool fragments (Luke 1974). During expressway construction, scattered human bones and coffin fragments were uncovered, but no systematic investigation took place (W. Max Witkind, personal communication to $T$. $R$. Hester, 1975; materials on file at UTSA).

Bob Dunphy collected artifacts from Brackenridge Park in 1963, primarily from the Polo Field (41 BX 264); this collection is now stored at the witte Museum. The exact provenience of the material is unclear, however, as there are no field notes and only one penciled sketch map with the material. Prior to Dunphy's work, the entire park and golf course had been designated as 41 BX 13, a single site with no internal differentiation. This single site designation was too vague to be of much use, for as the present survey has demonstrated, there are several discrete (rather than one continuous) areas of prehistoric activity that would be masked by the singie site designation.

A small 1ithic scatter west of the golf course on Magnolia Drive (Fig. 1; 41 BX 293) was reported to T. R. Hester in 1975. A Frio point was recovered from this site.

\section{Survey Procedures}

Prior to the initiation of the survey, it was decided that Fox would report any evidence of prehistoric occupation or activity to the north of St. Mary's Street in conjunction with her historic survey. She reports that no prehistoric material was found.

That area of the park and golf course surveyed by the Katz crew is estimated to encompass approximately 333 hectares (135 acres; see Fig. 1). It is bounded by the Northeast Expressway on the south, River Road/North St. Mary's Street on the west, North St. Mary's Street on the north, and Broadway/ Avenue $B$ on the east. For convenience, the term "park" will be understood to refer to the entire survey area.

The survey team acquired excellent large-scale topographic maps of the park area from CGR Associates and from the San Antonio River Authority. After studying these, two survey parties of two to three persons each were organized for an intensive coverage of the area. Each team surveyed on foot, maintaining contact and orienting themselves by means of park roads, trails and the San Antonio River. All evidences of prehistoric activity were recorded, and $100 \%$ of the survey area was covered. Cultural material was collected from each activity area located, including all diagnostic and shaped artifacts and a random collection of chipped stone flakes. The collection was made with the intent of establishing the qualitative presence (or absence) of tool types rather than obtaining any quantitative data. Field notes were maintained for every aspect of the survey, and site forms 


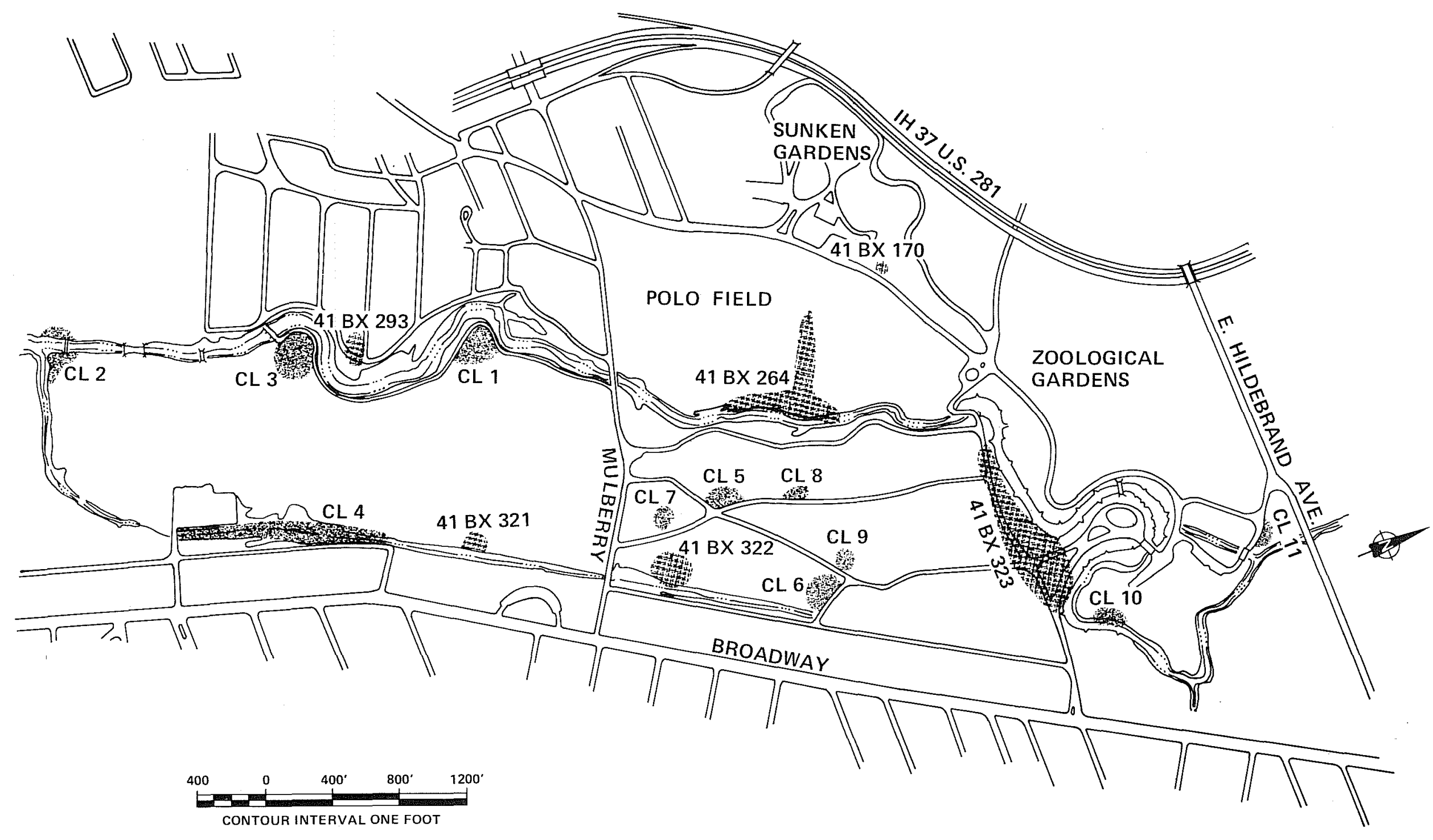

Figure 1. Map of Brackenridge Park and Brackenridge Golf Course. Shown are the approximate locations of prehistoric sites and collecting localities recorded during the survey. 
were completed where appropriate. All collected material was bagged for subsequent cleaning and cataloging at the Center for Archaeological Research.

Results of the Survey

Four prehistoric archaeological sites and 11 collecting localities were recorded during the survey. As employed in this report, the above terms are defined as follows:

A site is an area characterized by a concentration of artifactual material and has definite spatial boundaries. The degree of material concentration, the extent of this material on the surface and the distinctive nature of the boundaries are relative considerations, not so much between sites as in comparison with collecting localities.

A collecting locality is an area which has a scattering of artifacts which are neither in sufficient quantity or concentration nor in an adequately definable spatial extent to warrant a site designation.

An additional term used here is lithic scatter, defined as a concentration of chipped stone debris, shaped stone tools and/or grinding implements.

\section{Sites}

Four prehistoric sites were recorded in Brackenridge Park. A11 are 1ithic scatters, exhibiting a concentration of chert flakes; scraping, cutting and piercing tools; burned limestone rocks and land snails. Whether the latter have a cultural implication is unknown at present (however, see Hester and Hill 1975). Culturally diagnostic artifacts were extremely rare at these sites, due both to considerable relic hunting by several generations of park visitors and to various park construction projects. Two diagnostic artifacts were found, however, both dating to the latter part of the Archaic period (ca. 1000 B.C.-A.D. 1000).

41 BX 321 (Fig. 2,a) is located on the west bank of a north-south drainage ditch which separates the Brackenridge Golf Course from Lion's Field (Fig. 1). This lithic scatter was damaged by the drainage ditch and associated sewer lines constructed through it. Nevertheless, in the western wall of the drainage ditch, a cultural deposit was noted at approximately $30 \mathrm{~cm}$ below the surface. Irate golfers, unwilling to allow us access to the fifth fairway, hindered our overall areal estimate of the site; its estimated extent is at least $45 \mathrm{~m}$ north-south by at least $15 \mathrm{~m}$ east-west. No shaped tools were found at this site, although one of the utilized stone flakes may have been used as a scraping tool.

41 BX 322 (fig. 2,b) is situated in a flat, heavily wooded section of the park bounded by Avenue B, Mulberry and Wilderness Roads, with heaviest concentration about $60 \mathrm{~m}$ west of the drainage ditch paralleling Avenue $B$ (Fig. 1). The site exhibits a scattering of lithic debris, burned rock 

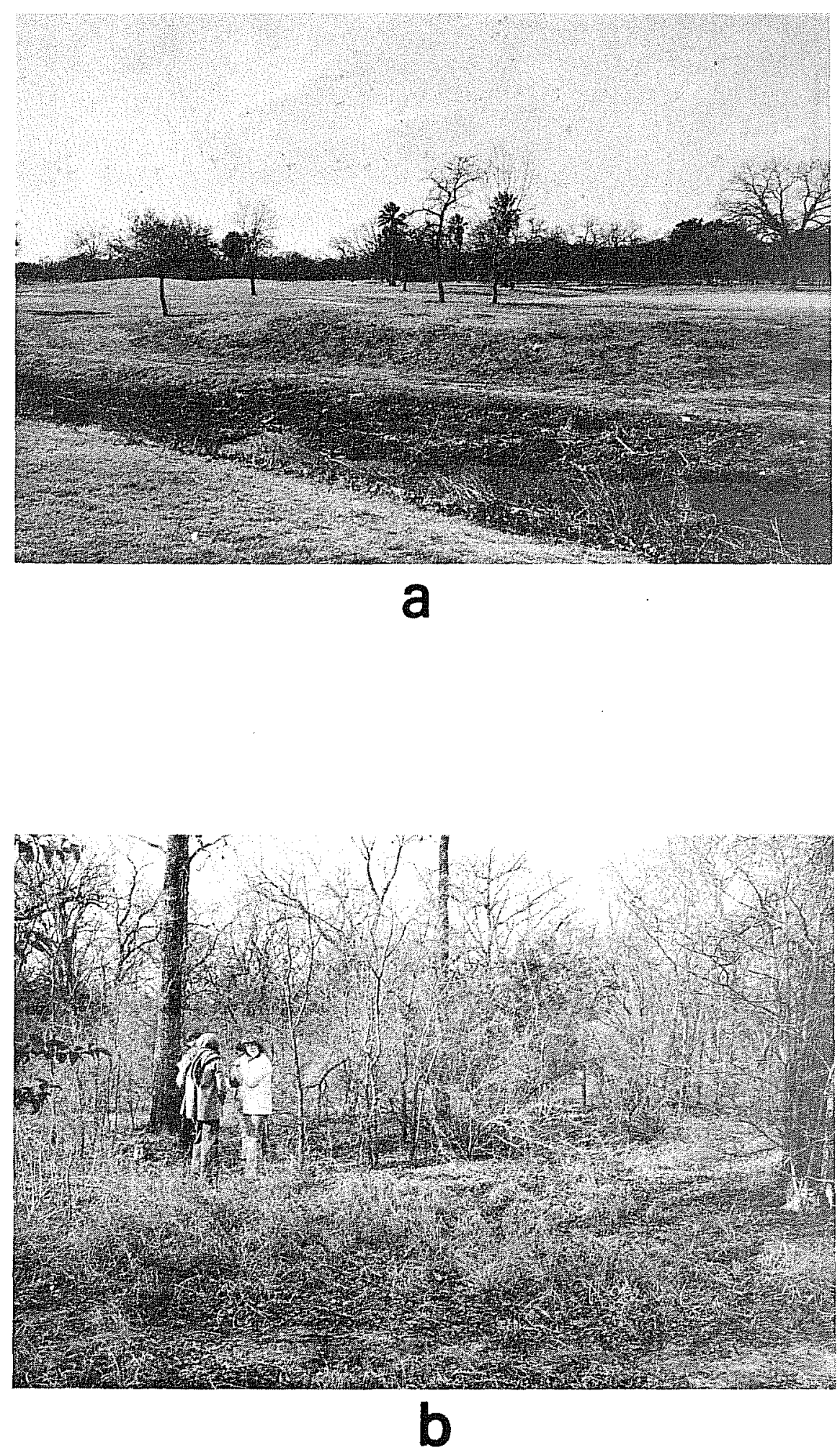

Figure 2. Views of Prehistoric Sites. a, view of $41 \mathrm{BX} 32$, looking southwest from Lion's Field; b, view of 41 BX 322, looking north. 
and land snails. Ground cover presented some problems, as artifacts were difficult to find under the grass and leaves. However, when these were brushed aside, flakes were often located. In addition, artifacts were occasionally noted on the horse trails that run in several directions through this area. Based on available evidence, it does not seem that this site represents a substantial occupation. It was perhaps a temporary campsite or possibly a specialized activity area. Its location at some distance from the San Antonio River and the small amount of cultural material relative to sites 41 BX 323 and 41 BX 264 substantiate this provisional interpretation. One scraping and/or cutting tool was among the material collected from this site.

41 BX 264 (Fig. 3,a), the Polo Field site, is an extensive scatter of chipped stone flakes and tools associated with a considerable amount of burned limestone fragments. This site has been known and collected by San Antonio residents for many years, but thick sod now covers and protects it from casual disturbance. It is only on the periphery of the Polo Field and in the adjacent horse corral, where the ground cover is absent, that artifacts appear on the surface. A smal7 excavation by the City Water Board was open during the survey, and its backdirt pile was literally covered with chipped stone flakes and artifacts. The walls of their $3-m^{2}$ pit exhibited cultural materials to a depth of at least $25 \mathrm{~cm}$. This pit was located about $25 \mathrm{~m}$ south of the baseball diamond, in front of the Polo Field scoreboard.

Artifacts from the corral area were kept separate from the Polo Field collection, as there were differences in the two areas. The former had fewer artifacts on the surface, and these were primarily heavy bifaces made on locally obtained chert cobbles. Much the same type of specimens appear in the Dunphy collection stored at the Witte Museum. The specimens from the Polo Field were primarily the shaping and finishing flakes of more finely made chipped stone tools, the flakes being thinner and smaller than those found at the corral.

One diagnostic artifact, a projectile point fragment, was found at the northeast corner of the Polo Field where a small depression drains into the San Antonio River. The straight, broad, parallel-sided base, prominent barbs and overall size suggest that this point is of the Castroville type (Suhm and Jelks 1962:173), a Middle Archaic dart point with radiocarbon dates in central Texas between 2810 and 1910 B.P.* (860 B.C.-A.D. 40, according to Weir 1976:64). Points in the Dunphy collection included Pedernales and Nolan (Middle and Early Archaic forms, respectively) and other earlier Archaic types.

The concentration of heavier tools near the corral may indicate a specialized activity area. Woolford (1935) augments this interpretation with his description of the area:

* B.P.: before present, as calculated from A.D. 1950. 


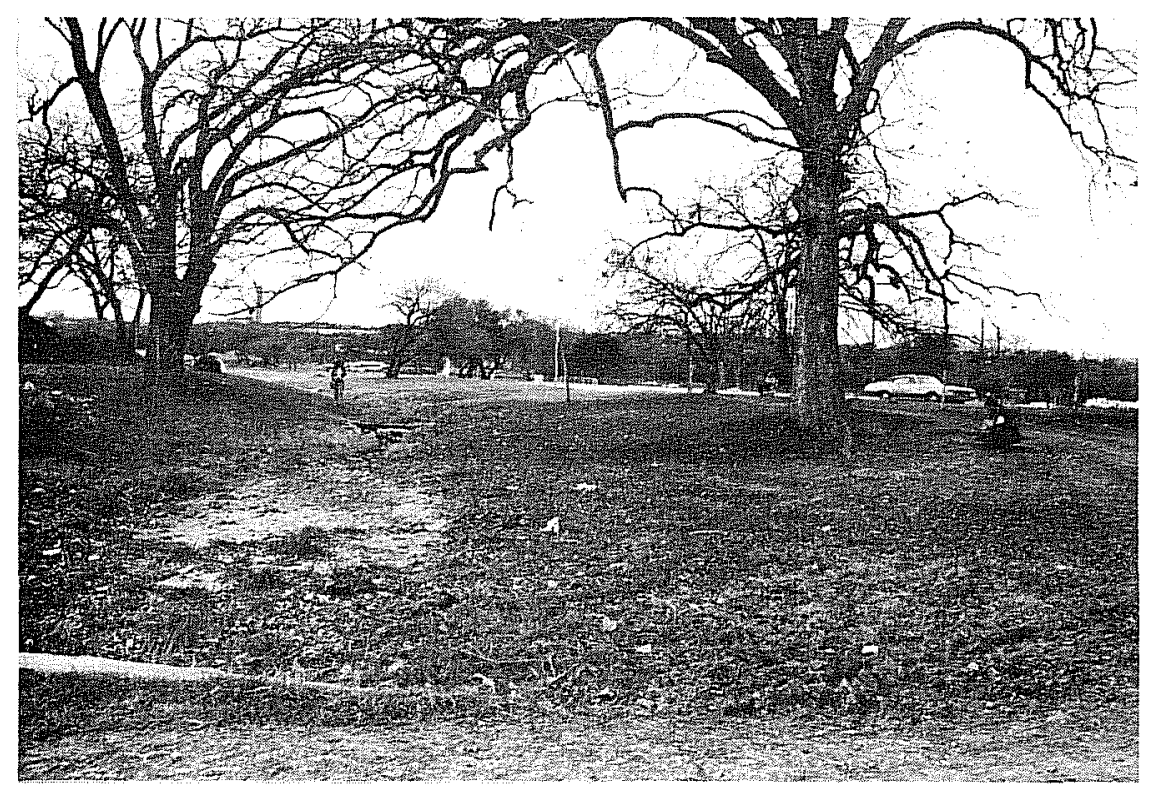

a

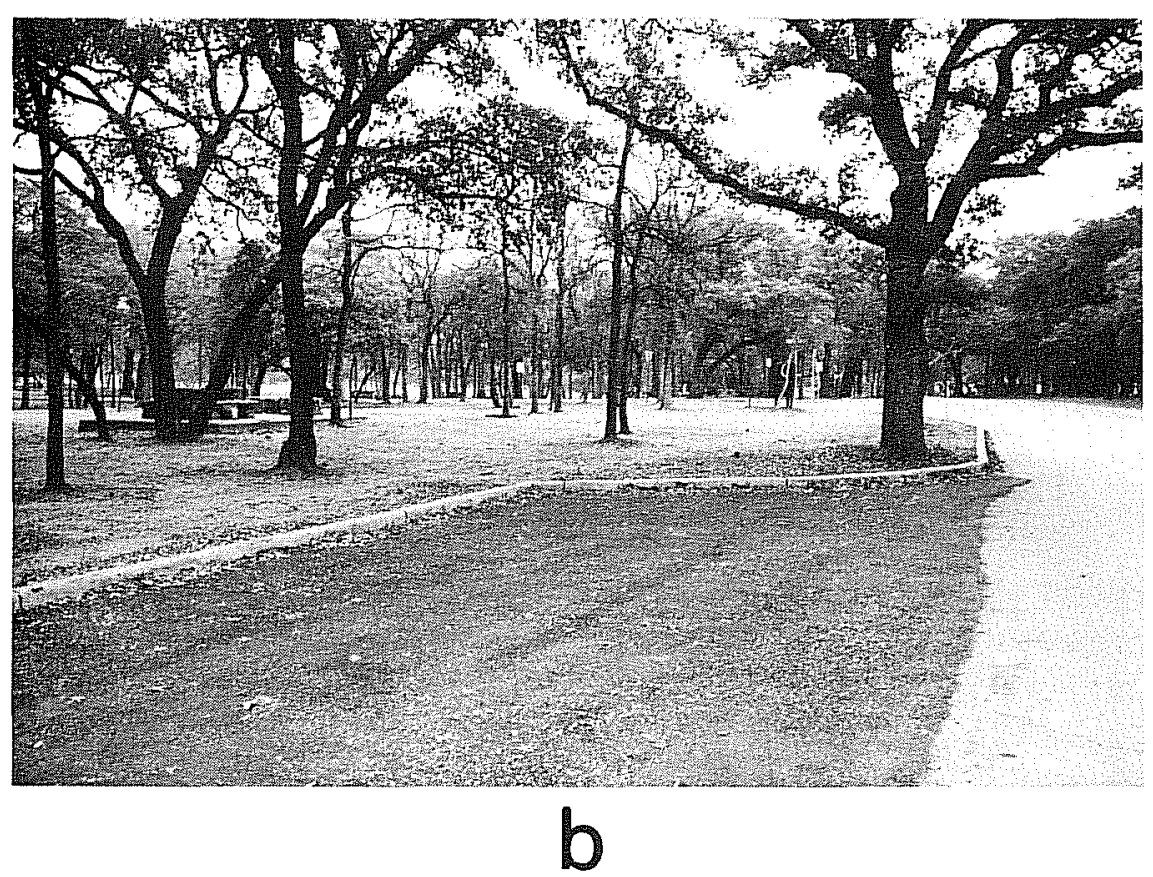

Figure 3. Views of Prehistoric sites. a, view of 41 BX 264, looking west; b, view of $41 \mathrm{BX} 323$, looking northeast. 
- . on the spot just south of the polo field, now cleared and used as a practice ring was formerly a skinning camp. This ground was clear of all small flint flakes, but was covered with many knives of all kinds. Evidently it fringed upon a village site and was used by squaws for dressing hides.

The Polo Field itself, with its substantial amount of material, spatial extent, depth of deposit and variety of materials, indicates that it may have been an occupation area used for several seasons by more than a single family. It seems to fit into the base camp category as defined for Bexar county by Fawcett $(1972: 25-26)$ :

- . these sites are Targe normally thick sites which are located on the second terrace of large creeks and rivers. They usually contain large numbers and great varieties of tools which were deposited during periodic repeated occupation of the site. Hearths and firecracked rock occur along with points, scrapers, thin bifaces, retouched pieces, notches, gravers, and in a few cases cores or thick bifaces. Debris consists primarily of secondary flakes (exterior covered by $75 \%$ or more cortex) and interior flakes (exterior covered by less than 25\% cortex). Mussel shells occur here if anywhere. Manos and metates occur in small numbers in these sites indicating some plant food processing although it appears that hunting was the major form of subsistence, and animal bones are often present if preservation is good. Sites of this type are well drained and sheltered by the valley in which they are situated. Base camps appear to have been centers of seasonal wandering bands at which they prepared foods and finished tool manufacture. These sites appear to have been occupied possibly by the largest population and longest single occupation compared to the other site types.

41 BX 323 (Fig. 3,b), the Paddle Boat Concession site, is a substantial lithic scatter measuring approximately $300 \mathrm{~m}$ by $75 \mathrm{~m}$. It is situated along the river banks from the Wilderness/Tuleta Road intersection east to the rear of the Witte Museum on the east bank of the river (Fig. 1). The area of maximum concentration is immediately north of Tuleta Road, on both sides of Brackenridge Park, especially between the intersection and the river's edge northwest of the intersection. Collecting locality \#10, across the river from the Witte Museum, may have also been part of this site (Fig. 1).

This site is presently in a very popular picnic area and is constantly being eroded due to lack of ground cover. Small shovel tests excavated randomly throughout the area indicated that there are still more than $30 \mathrm{~cm}$ of cultural deposit remaining undisturbed below the present ground surface.

One projectile point was recovered from $41 \mathrm{BX} 323$. A medium-sized, stemmed dart point with side notches and a concave base, this point most closely resembles the Late Archaic Frio type (Suhm and Jelks 1962:195) with dates ranging from 1970 to 670 B.P. (20 B.C.-A.D. 1280; Weir 1976:64). 
It is difficult to make further statements about these sites without any excavation, but a few general observations might be in order. Sites 41 BX 323 and $41 \mathrm{BX} 264$ are substantial sites on the first terrace above the river and close to the main channel. Their artifact inventories are similar, and they are both probable occupation sites. Diagnostic artifacts from both sites indicate occupation during the Archaic period. This does not preclude the possibility of any occupation either before or after this period, but only diagnostic Archaic artifacts were located in this survey and are present in the Dunphy collection. Sites 41 BX 321 and 41 BX 322 are smaller sites located farther away from the river. These may represent small camps or specialized activity areas. 41 BX 321 had more overall material than 41 BX 322 on the surface, as well as having a greater variety of flake sizes, shapes and colors. Artifacts from 41 BX 322 were primarily limited to large flakes, all manufactured from a local tan chert.

\section{Collecting Localities}

Eleven collecting localities were recorded during this survey. These are designated by a "CL" prefix, followed by an abbreviation of the USGS topographic quadrangle on which they are located and a consecutively numbered suffix. CL-SAE-10, for example, is the tenth collecting locality to be recorded in the USGS San Antonio East quadrangle. Unlike sites, these localities are not officially recorded with the Texas Archeological Research Laboratory in Austin. A11 but one of the localities were characterized by chert flakes, indicating the manufacture and/or maintenance of chipped stone tools at these locations. Several localities had scraping and cutting tools as well. Burned limestone, indicative of hearths, occurred at two of the localities.

Two collecting localities deserve special note. The artifact inventory of CL-SAE-1 consists of a number of chert cobbles with flakes randomly removed from their surfaces. It is likely that these were deposited by the river and provided a source of raw material for chipped stone tool manufacture. As this locality (Fig. 1) is immediately adjacent to River Road (many samples were splattered with road tar), the river and the golf course, it is impossible to assess whether this was originally extensive enough to have been a prehistoric quarry or workshop. There must have been more extensive use of the golf course area; however, as S. W. Woolford's 1935 description states:

I have found some pottery along the river near the tee on No. 9 of the Golf Course, and one old fire hearth, less than ten feet from the edge of the fairway, where beneath the growing bushes a fire reddened arrow still lay upon the hearthstone.

CL-SAE-8 contained a considerable number of smal1 chert flakes eroding out of a gully wall in the area of horse trails immediately west of Wilderness Road (Fig. 1). It is felt that a few ridges are all that remain of a more substantial site, removed through natural erosion and the construction, maintenance and use of the horse trail. 
Summary and Recommendations

This most recent survey of Brackenridge Park has resulted in the identification of 11 collecting localities and four archaeological sites. A11 of the four sites have been partially destroyed and are in danger of further disruption; the collecting localities, which are also in danger, may be all that remain of previous archaeological sites. A similar situation exists on the Incarnate Word College property, adjacent to Brackenridge Park. In this area, that portion which has been modified by academic and convent buildings contains many collecting localities but no sites; the portion which has not been deve1oped, on the west bank of the river, is characterized by eight well-defined sites. Any further modification to Brackenridge Park may well unearth scattered archaeological remains, although probably no new sites. The protection and preservation of known sites is, therefore, of primary importance.

Site 41 BX 321 may be impacted by modifications to the drainage ditch between the golf course and Lion's Field. While construction will not remove any portion of the site (CGR Associates, personal communication), the heavy equipment traveling over the site is likely to cause damage. Studies conducted on Forest Service lands in California, for example, have shown that tractors turning around on archaeological sites do more damage than chaining operations on the same land (DeBloois, Green and Wylie 1975).

Site 41 BX 322 does not appear to be a very substantial site, although the ground cover probably conceals the majority of the artifacts and any features. Limited testing should be conducted if there are to be any modifications to Avenue B, Mulberry or Wilderness Roads, or to the Avenue B drainage ditch.*

Site 41 BX 264, the Polo Field Site, is an extensive site, the majority of which is covered and protected by a thick layer of sod that forms the present surface of the Polo Field. A small pit dug immediately beyond the field, in front of the scoreboard, was littered with artifacts. With this in mind, it is recommended that, before any further excavation into the surface of the field or its immediate environs, an archaeologist should be notified so as to be available for observation. However, modifications of an extensive nature to the field itself should not be carried out without prior archaeological investigations involving excavation.

Site $41 \mathrm{BX} 323$, the Paddle Boat Concession site, is located in a popular picnic spot in the busiest part of the park. Wearing down of the ground surface seems to have uncovered this deposit, which erodes away daily. It was noticed that fill had been brought into the picnic area and spread out along the bank of the river. It is recommended that more fill be brought in to firmly cap the site area, thus protecting it from further erosion by rain run-off and foot traffic by park visitors. If modification that would further disturb the site is planned, intensive excavation prior to such disturbance is strongly recommended.

Testing was carried out at 41 BX 322 in December 1977 (see Fox and Frkuska 1978). 


\section{THE HISTORIC SITES}

An on-site survey of Brackenridge Park was conducted by Anne Fox, with the assistance of Shirley Van der Veer, during the week of December 23, 1976. During the survey, numerous historic sites were identified, recorded and photographed. These sites included water control features (e.g., Spanish acequias, Water Works Company canals and structures), industrial features (lime kiin, rock quarries, Alamo Portland Cement plant) and those features used for recreational or educational purposes (e.g., Lambert Bathing Beach, Municipal Zoo, Oriental Gardens). Brief descriptions of each of the recorded sites follow, using the categories of the site's function as an organizing principle. The number following each entry refers to its location on the map (Fig. 4).

\section{Water Control Features}

One of the principal reasons for the first Spanish settlement of San Antonio was the availability of abundant springs of water in the vicinity to be used for irrigation as well as for the everyday needs of the settlers. Therefore, the first order of business was the construction of acequias, or ditches, to bring the water to the settlement. As more irrigated land was needed, more acequias were built. When, in the late 19th century, the acequias were no longer sufficient to provide water for the growing town, pressure from the river was used to force water into a large reservoir on the ridge to the northeast of town. By the turn of the century, the San Antonio springs were no longer able to supply the town. Artesian wells became the principal source of water, and the acequias were abandoned and gradually filled in and forgotten.

\section{Alamo Madre Acequia (\#1)}

Built in the 1720s, soon after the founding of San Antonio, this ditch carried water to Mission San Antonio de Valero (later known as The Alamo) and to irrigated farm lands to the north and east of the mission (Habig 1968:45). It left the San Antonio River near Pershing Street, crossed Broadway and ran south parallel to Broadway. One branch continued east of the mission, going south toward Mission Concepción, while another branch ran through Mission San Antonio de Valero and returned to the river north of Commerce Street.

Upper Labor Acequia (\#2)

This irrigation ditch was constructed to irrigate the lands between the San Antonio River and San Pedro Creek. Commissioned by Don Juan Maria de Ripperda, Governor of the Province of Texas, the acequia was built during the years 177678. It began at the west side of the San Antonio River, at the northern end of 


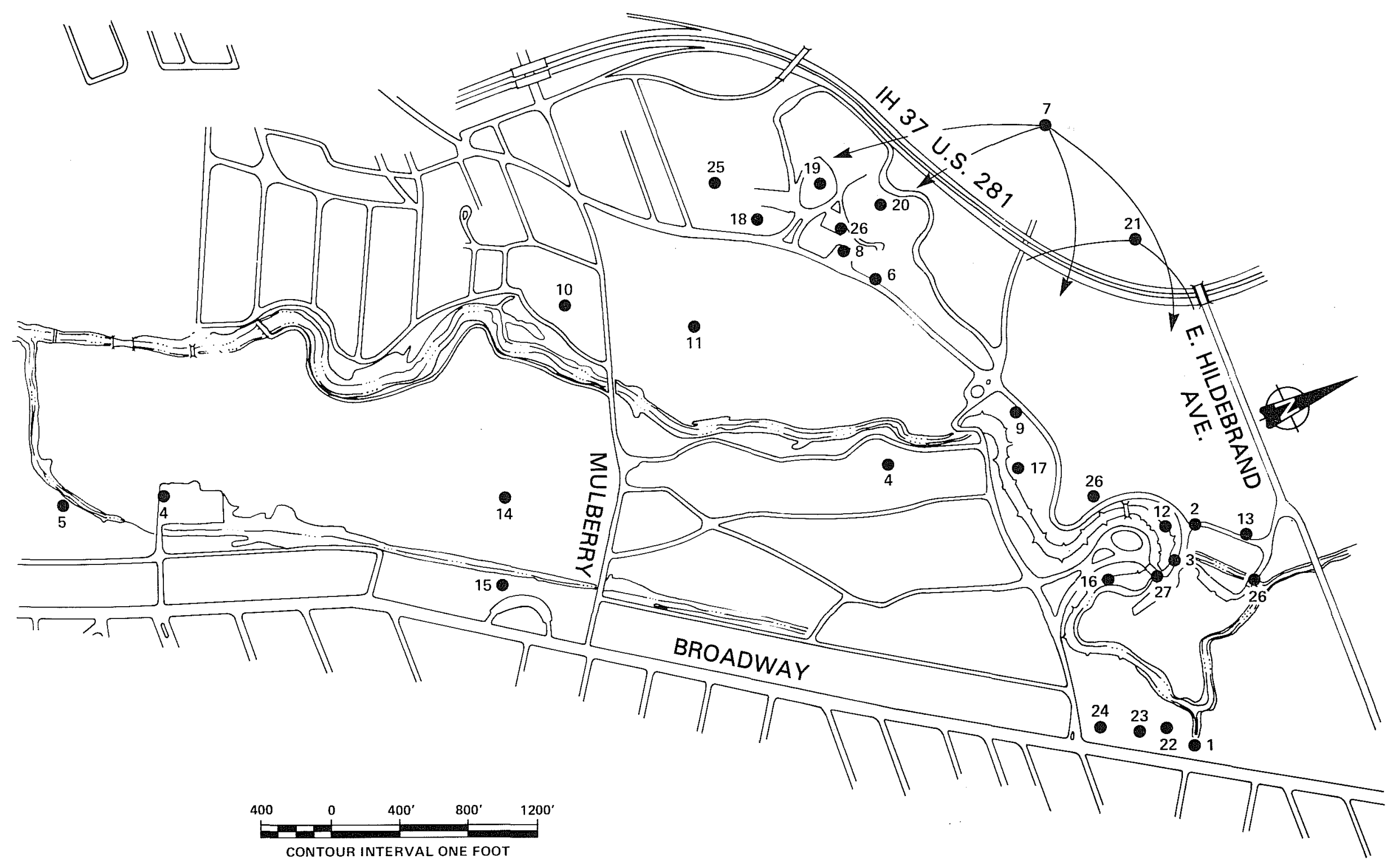

Figure 4. Historic Sites Map of Brackenridge Park and Brackenridge Golf Course. Shown are the locations of historic sites recorded during the survey. Kep to map numbers is on facing page. 
what is now Brackenridge Park, and followed the street presently known as St. Mary's for a distance; it then cut across to San Pedro Avenue. At this point it joined the San Pedro Acequia at West Laurel Street (Corner 1890: 46-50). The acequia watered about 600 acres of farm land and was maintained until the end of the 19th century. A small portion of the Upper Labor Acequia is still in use in the Municipal Zoo.

Water works Building and Canal (\#3; Fig. 5,a)

These were constructed in 1877-78 on acreage leased from the city by $\mathrm{J}$. B. Lacoste \& Associates, S. A. 01 iver and W. R. Freeman (Baker 1978:7). The San Antonio Water Works Company constructed a raceway and pumphouse, which still stand in the park near the paddleboat area. The single-story 7 imestone structure housed an office area with double turbines below. The pumps and canal raised water into a reservoir which was excavated at the summit of the hill in the area now known as Manchke Park (see Black 1976), and from there the water was conducted by gravity flow to Water Works customers through a series of cast iron mains (Baker 1978:7). Unfortunately, the company did not immediately attract a sufficient number of patrons to remain financially sound (Maclean n.d.:6). On October 8, 1883 the controlling interest in the company was sold to George W. Brackenridge. The Water Works flourished under Brackenridge's guidance, and soon the demand by customers exceeded the capacity of the first Water Works facilities.

\section{The Second water works Building and Canals (\#4; Fig. 5,b)}

This handsome two-story limestone structure, which still stands in the area near the golf course, was constructed in 1886 (San Antonio Water Co. 1921:4). It too propelled water into the Manchke Park reservoir, which had been enlarged for additional capacity. Canals were constructed 1inking this structure with the first pumphouse. As increasing needs once again outgrew the Water Works capacity, steam-powered pumps were installed, and finally artesian wells were drilled. The Water Works buildings in Brackenridge Park apparently ceased pumping soon after the turn of the century.

In 1928, sculptor Gutzon Borglum renovated the abandoned pumphouse for use as a studio, leasing it from the city until 1937. It has since housed art classes and the Handweaver's Guild (Woolford \& Quillin 1966:121,305) and was most recently used as a warehouse for the Witte Museum. Although many residents refer to this structure as "The $01 d$ Mil1," it was never used for milling purposes.

\section{Industrial Structures}

The presence of water, water power and abundant 1 imestone in the Brackenridge Park area encouraged a number of industrial enterprises to locate there in the 19th century, previous to the development of the park. 

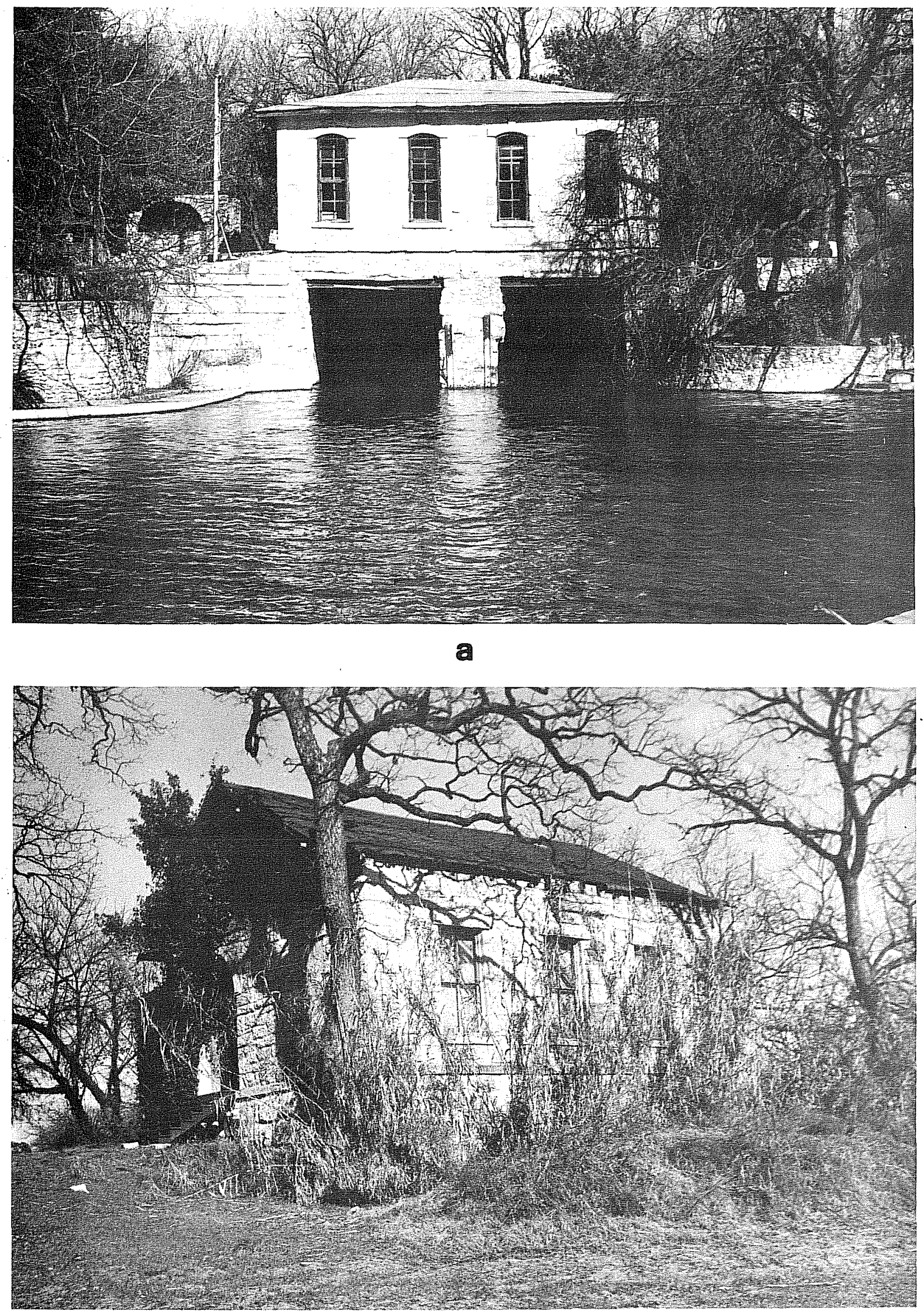

\section{b}

Figure 5. Views of Historic Sites. a, first Water Works building; $b$, second Water Works building. 
Garza Mill (\#5)

The Garza family acquired property at the south end of the park in 1823 (Webb \& Goeth 1905), and at some time soon after that date they built a grist mi11 on the east bank of the river (Barnes 1910:244). The exact location of the mi11 is no longer known. It is possible that Mill Race Street, north of Josephine and west of Broadway, is in some way connected with this mil1.

old Lime Kiln (\#6)

This feature, similar to those at Mission Espada, may be Spanish in origin. It is a circular feature approximately $3 \mathrm{~m}$ in diameter.

\section{Rock Quarries (\#7)}

Outcrops along the bluff on the western edge of Brackenridge Park provided the limestone used for many of San Antonio's structures, beginning with the first German masons about 1840. Landmarks such as the Menger Hotel were built of stone from these quarries (Woolford 1963:134). By 1844, the City found it necessary to pass a motion that "a11 persons that may wish to procure rock from any quarry belonging to the Corporation shall first obtain a license (sic)" (Journal of City Council 1847:122). In 1876 these quarries were rented at $\$ 10$ per month (ibid. 1876:225).

The Alamo Portland and Roman Cement Plant (\#8; Fig. 6,a)

This plant, the first of its kind west of the Mississippi, was begun in 1880 and served as the headquarters of this company's operation until 1908, when it was moved to the present site in Alamo Heights. The original quarries were later incorporated into the landscape of the Sunken Gardens. In addition to the cement business, the company also sold lime and building stone, using their kilns for burning cement as well as lime (Baumberger n.d.:2). At the time the decision to move to their own site was reached (they had leased land from the City until this time), the company facility included quarries, kilns and mills for grinding raw materials, as well as a series of buildings which served as homes for the plant's workers. A single chimney, the ruins of a kiln and an outbuilding remain in the park today. In 1917, City prison labor was used to construct a large thatch-roofed structure in front of the old cement kiln for use as a Mexican market. Pottery, baskets and other native crafts were made and sold there from 1917 until 1947 (Lochbaum n.d.). Shortiy after the Second World War, several of these buildings were occupied by an artist's colony, known locally as "The Lime Kiln" or "Sunken Garden Art Colony" (San Antonio Express Magazine n.d.). 

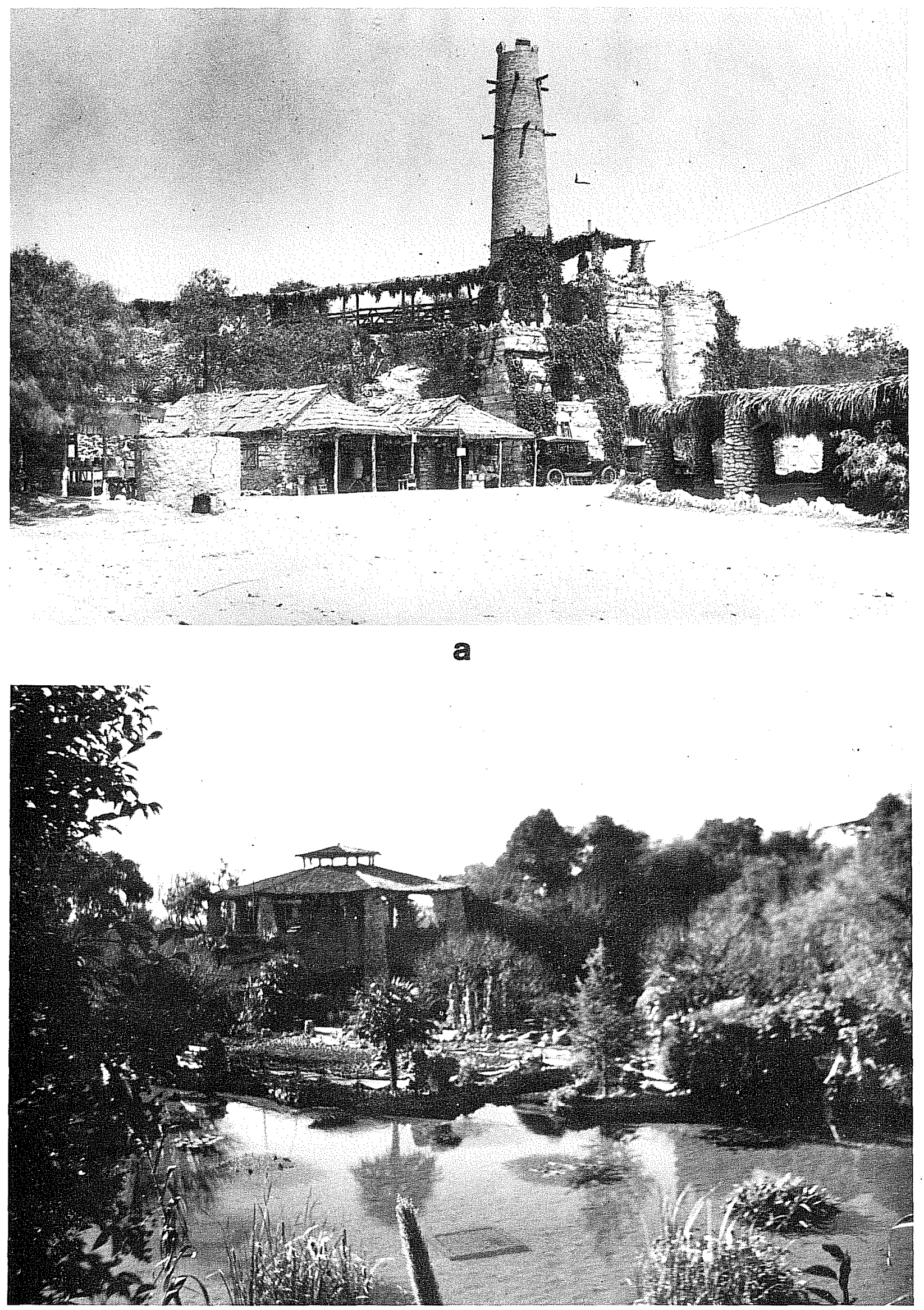

b

Figure 6. Views of Historic Sites. a, Alamo Portland and Roman Cement Works (from DRT Library photographic collection); b, Sunken Gardens. 
Confederate Tannery (\#9)

This facility was built in the vicinity of the present zoo. The Confederate Government purchased 78 acres from the City in 1863 for $\$ 5000$ for the purpose of operating a tannery, which began by processing wool and was later converted to process leather. The tannery was plagued by lack of equipment, raw materials and manpower. Only four small buildings were ever constructed, despite original plans for massive production (Kerby 1972:261). Three years after purchase, the property was turned over to the "Freedman's Bureau," an organization established after the Civil War (Heusinger 1951:30). In 1869 the City bought the land back for $\$ 4500$ (King 1950).

\section{Recreational Features}

Many such facilities have operated through the years in Brackenridge Park. Those described here are ones which no longer exist and are interesting and worthy of noting and locating for the information of the park visitor. No attempt has been made to include those operations which are currently present in the park, such as the golf course, the Brackenridge Eagle, the sky ride and the Brackenridge Stables.

Charro Field (\#10)

This area, once used by the Charro Association, is said to have had an arena-like wooden frame structure on it that was destroyed in a fire.

Polo Field (\#11)

This field was leased for five years by the San Antonio Polo Club (1952-57). After the lease expired, the City leased the property to the Driving Range, which had previously sublet the area from the Polo Club. The Sheriff's Posse leased land for stable, office and arena adjacent to the Polo Field (Balmos 1959).

Lambert Bathing Beach (\#12)

The beach, named for Park Commissioner Ray Lambert (Schuchard 1951:57), was a popular swimming area from its opening in 1917. It was closed in 1950, partly as a result of a polio epidemic in the city. The "Beach" was built of concrete and stone on an oxbow of the San Antonio River. On the north side of this lagoon-like area there still remains the ruins of a row of stone and mortar changing rooms.

Donkey Rides (\#13)

These free rides were begun by the Rotary Club in the 1920s (Federai Writers Project 1938:79) and were situated near the building which currently serves 
as headquarters for park administration. This building, designed to resemble the Alamo, was constructed by Park Commissioner Ray Lambert as a barn and hayl oft for the donkeys (Woolford and Quillin 1966:37). The rides were discontinued in the 1940s (Ed Davis, personal communication).

San Antonio Jockey Club (\#14)

The Club, organized in 1889, constructed a 3/4-mile track and clubhouse just west of the present Lion's Field (Heusinger 1951:46). The clubhouse, built about 1899, was later used as a residence for the park gardener and in 1917 became the Brackenridge Golf Club headquarters (Newcomb 1962). It was a twostory frame structure, with encircling porches on both stories. The building was razed in 1923 when the new clubhouse was built. Horse races were held weekly on the track, which was also used for bicycle races held by the "Alamo Wheelmen Club." Racing on the track ceased in 1910 (San Antonio Light 1938).

\section{Lion's Field (\#15)}

This 9.5-acre tract was acquired by the City between 1916 and 1920. It was the first supervised playground facility in San Antonio, equipped and maintained by the Lion's Club until creation of the present Recreation Department in 1928 (King 1950).

\section{Joske and Koehler Pavilions (\#16 and \#17)}

Two large stone pavilions have been built on the park as memorials to San Antonio citizens. In 1925 Alexander Joske presented the Joske Pavilion to the City, dedicated to his father JuTius and brother Albert. Located on the land donated to the park by Emma Koehler is the Otto Koehler Pavilion. This structure was donated by Mrs. Koehler in honor of her husband and built by the Works Progress Administration in 1935 to 1937 (information taken from pavilion markers).

\section{Educational Facilities}

San Antonio is fortunate to have a number of fine educational facilites located in Brackenridge Park. These are enjoyed by many thousands of visitors each year and are known throughout the state for the quality of their exhibits and programs.

Anna Hertzberg Hall of Music (\#18)

This structure has been leased by the Tuesday Music Club since its construction in 1950. Anna Hertzberg organized the club in 1901 (Institute of Texan Cultures 1974:14), and the building was dedicated to her. It is still in use. 
Sunken Garden Theatre (\#19)

This amphitheatre was constructed by the Works Progress Administration in 1936 and has been used for outdoor concerts, plays and operatic performances since that time.

Sunken Gardens (\#20; Fig. 6,b)

Originally called the "Japanese Tea Garden," the name was changed first to the "Chinese Tea Garden" and then simply to the "Sunken Garden" during the Second World War era. The gardens were built by prison laborers on the site of an abandoned rock quarry. The gardens contain both exotic floral specimens brought especially from Japan by Park Commissioner Ray Lambert as well as a wide variety of native plants. The pavilion over the garden was used as a tea house which was run by a Japanese family (Mr. and Mrs. K. E. Jingu) who lived in the structure that now serves as a concession stand adjacent to the pavilion (Sawyer 1974).

Municipal zoo (\#21)

This facility was established in 1914; prior to that time, the only zoo was a private collection in San Pedro Park. The first animals placed in the new zoo were a herd of buffalo and elk donated by George W. Brackenridge which had been grazing in the area that is now the golf course (King 1950).

Reptile Garden (\#22)

Opened in 1932 as an adjunct to the Witte Museum, the gardens featured rattlesnake viewing areas and a "rattlesnake fry." Both the gardens and the "fry" were conceived by Ellen Schultz Quillin in an effort to attract more visitors to the Museum (Woolford and Quillin 1966:62). The stone buildings that remain were built in 1934 (ibid.:78). In 1950 the snakes were moved to the zoo and replaced with alligators. As with the rattlesnakes, this was a popular exhibit and remained so until the closing of the garden in 1975 (San Antonio Express-News 1975).

Texas Pioneers, Trail Drivers and Rangers Memorial Building (\#23)

The U. S. Centennial Commission furnished the funds for this building, which was completed in 1937. It currently serves as the headquarters of the Texas Trai1 Drivers Association (Heusinger 1951:71). The bronze monument to the Trail Drivers which stands in front of the building was designed by Gutzon Borglum in 1925 and was cast in bronze by his son in 1947. The monument bears this legend: "Erected to perpetuate and honor the memory of the old Trail Drivers of Texas who drove over ten million long horned cattle to northern markets between 1866 and 1895." 
Witte Memorial Museum (\#24)

The museum was built in 1926, largely through the efforts of Ellen Schultz Quillin, its first director. An excellent volume detailing the history of the museum was written by B. C. Woolford and E. S. Quillin in 1966, entitled The Story of the Witte Memorial Museum, 1922-1960. The museum was built around a core collection of artifacts collected by naturalist H. P. Attwater.

\section{Miscellaneous Features}

Kampmann House (\#25)

The Kampmann property, which includes a stone house built in the late 19th century, was purchased from the City in 1852. It remained in the possession of the Kampmann family until it was sold to the City, a part in 1905 and the balance in 1916 (Bexar County Deed Records). A rifle range was located to the west of the house in the 1920s (Wesley W. Reed, personal communication).

\section{Rodriguez Structures (\#26)}

Built of concrete reinforced with steel, these creations were the work of Dionicio Rodriguez, who carved and painted them in the 1920s. The gate for the Sunken Gardens, various benches and gazebos around the park, and a footbridge across the canal and acequia at the northern entrance to the park are all attributed to him.

\section{Iron Truss Bridge (\#27)}

This bridge was built in 1890 by the Berlin Iron Bridge Company of East Berlin, Connecticut, and was originally situated downtown. It was moved to the park in 1937 (0'Neill, Perez, Larcade 1972).

\section{Recommendations}

Historic sites in the park take several forms and suggest various methods of treatment to insure their preservation. A number are standing structures which should be renovated where necessary to retain the character of their original design; they should be kept in good repair to forestall further physical deterioration. Wherever feasible, a contemporary use should be found for buildings such as the Sunken Gardens Theatre, Water Works and Kampmann house which is in sympathy with their original use and does not detract from their historic identity. The Rodriguez sculptures, the pavilions and the cement kiln must be kept in good repair in order to discourage vandalism. Hopefully, a use will be found for the Reptile Garden to forestall its gradual decay. 
Buried features such as the old lime kiln and associated foundations and the acequia channels should be carefully marked and kept covered with soil. General location of past activities such as the donkey rides, the Garza mi11 and the Jockey Club and race track should be marked with appropriate plaques.

\section{SUMMARY AND CONCLUSIONS}

The surveys have located and identified 15 prehistoric and 27 historic sites and features within the boundaries of Brackenridge Park. These sites reflect a variety of activities which have been carried out over a period of several thousand years. They are worthy of further research, interpretation for the public and preservation for future use and enjoyment wherever possible.

Future park development should take into account the location of these sites and avoid disturbing them, either by physical disturbance or by radical alterations to the immediately surrounding area. If it becomes necessary to disturb or remove any of these sites in the future, we strongly urge archaeological investigation in order to record as much as possible of their history and structure before it is destroyed.

Because of the large number of historic and prehistoric sites located within its boundaries, we recommend that the entire area of Brackenridge Park be nominated to the National Register of Historic Places as a Historic District. 


\section{REFERENCES CITED}

Baker, T. Lindsay

1978 A Brief History of the San Antonio Waterworks. Perspective. Society for Architectural Historians, Texas Chapter. March 1978:7-8.

Balmos, Dick

1959 The Brackenridge Story--How Park Grew. San Antonio Light, August 6.

Barnes, Charles Merritt

1910 Combats and Conquests of Immortal Heroes. Guessaz and Ferlet, San Antonio.

Baumberger, C.

n.d. Some History of Early Pioneer Days of the Cement Industry in West Texas. Ms. on file, Ellen Schultz Quillin Library, Witte Museum, San Antonio.

Bexar County Deed Records

1905 Warranty Deed. Eda and Theodore Meyer and Elizabeth and Caroline Kampmann to City of San Antonio. Vol. 242:318.

1916 Special Warranty Deed. Eda and Theodore Meyer; J. H., Ike, Robert Kampmann; and Eda and Joseph Frost to City of San Antonio. Vol. 491:422.

Black, Stephen L.

1976 An Historical and Archaeological Assessment of the Proposed San Antonio Botanical Center. Center for Archaeological Research. The University of Texas at San Antonio. Archaeological Survey Report 24.

Corner, $w$.

1890 San Antonio de Bexar. Bainbridge and Corner, San Antonio. DeBloois, Evan, Dee Green and Henry Wylie

1975 A Test of the Impact of Pinyon-Juniper Chaining on Archaeological Sites. The Pinyon-Juniper Ecosystem: A Symposium. Utah State University, Provo. 
Fawcett, William Jr.

1972 The Prehistory of Bexar County: A Study of Previous Work in South Central Texas. Lower Plains Archaeological Society Bulletin 2:23-43.

Federal Writers Project (WPA)

1938 San Antonio. An Authoritative Guide to the City and Its Environs. Clegg Company, San Antonio.

Fox, Anne A.

1975 An Archaeological Assessment of the Southern Portion of the 01mos Basin, Bexar County, Texas. Center for Archaeological Research, The University of Texas at San Antonio, Archaeological Survey Report 9.

Fox, A. A. and E. C. Frkuska

1978 Archaeological Monitoring and Testing at the Catalpa-Pershing Storm Drainage Project in San Antonio, Texas. Center for Archaeological Research. The university of Texas at San Antonio, Archaeological Survey Report 48.

Habig, Marion A., OFM

1968 The Alamo Chain of Missions. Franciscan Herald Press, Chicago. Hester, T. R. and T. C. Hill, Jr.

1975 Some Aspects of Late Prehistoric and Protohistoric Archaeology in Southern Texas. Center for Archaeological Research. The University of Texas at San Antonio, Special Report 1.

Heusinger, E. W.

1951 A Chronology of Events in San Antonio. Standard Printing Company, San Antonio.

Institute of Texan cultures

1974 The Jewish Texans. Encino Press, San Antonio.

Journal of the City Council

1847 License, Demanding persons to obtain. January 7, 1847.

1876 Niggli, E. \& Co., Granting petition of, that all Rock Quarries be rented at $\$ 10.00$ per month. March 7, 1876. JD-642-225. 
Kerby, Robert L.

1972 Kirby Smith's Confederacy, the Trans-Mississippi South, 1863-65. Columbia University Press.

King, Stewart

1950 Little Known Facts About Our Parks. Paper delivered at the President's Council, February 6, 1950. Copy in the files of the ElTen Schultz Quillin Library, Witte Museum, San Antonio.

Lochbaum, Patsy

n.d. Newspaper article in the files of the DRT Library, San Antonio. Luke, Clive

1974 Archaeological Investigation Along the Route of U.S. 281, from Mutberry Avenue to Tuxedo Avenue in San Antonio. Manuscript, Texas Highway Department, Austin.

MacLean, Bert J.

n.d. The Romance of San Antonio's Water Supply and Distribution. Press of San Antonio Printing Company.

Newcomb, J. P., II

1962 Some Notes on Brackenridge Park. Manuscript in the files of the Ellen Schultz Quillin Library, Witte Museum, San Antonio.

0'Nei11, Perez, Larcade, Architects

1972 San Antonio Histaric Survey. Vo1. 2. City of San Antonio, City Planning Department.

Orchard, C. D.

1966 Two Etcetera Lots in the Orchard Collection. Paper presented at the Texas Archeological Society Annual Meeting, San Antonio.

1974 The 0lmos Basin. Manuscript on file, CAR-UTSA.

San Antonio Express Magazine

n.d. Lime Kiln Colony. Files of Ellen S. Quillin Library, Witte Museum.

San Antonio Express-News

1975 Article on Closing of Alligator Garden. August 16, 1975. Files of Ellen S. Quillin Library, Witte Museum. 
San Antonio Light

1938 S. A. Racing at High Level in Gay Nineties. June 5, 1938.

San Antonio Water Company

1921 Memorandum in Regard to Metcalf's Report to Messrs. H. G. Edwards \& Sons, November 6, 1908. Files of Ellen Schultz Quillin Library, Witte Museum, San Antonio.

Sawyer, Eve Lynn

1974 Japanese Tea Garden Their Childhood Home. San Antonio ExpressNews, Ju1y 21, 1974.

Schuchard, Ernst

1951 100th Anniversary, Pioneer Flour Mills, San Antonio, Texas, 1851-1951. Naylor, San Antonio.

Suhm, Dee Ann and Edward B. Jelks

1962 An Introductory Handbook of Texas Archeology: Type Descriptions. Texas Memorial Museum Bulletin 4.

Webb and Goeth, Attorneys at Law

1905 Letter to Mr. Paul Poppy (sic), Galveston, Texas. August 17, 1905. Archives of DRT Library, San Antonio.

Weir, Frank A.

1976 The Central Texas Archaic. Ph.D. dissertation, Washington State University, Pullman.

Woolford, B. C. and E. S. Quitlin

1966 The Story of the Witte Memorial Museum, 1922-1960. San Antonio Museum Association.

Woolford, Sam W.

1935 Types of Archaeological Sites Found in Bexar County. Witte Memorial Museum Bulletin 4.

Woolford, Sam W., editor

1963 San Antonio, A History for Tomorrow. Naylor, San Antonio. 